\title{
Zoometric measures and their utilization in prediction of live weight of local goats in southern México
}

\author{
E. J. Dorantes-Coronado ${ }^{1}$, Glafiro Torres-Hernández ${ }^{1 *}$, O. Hernández-Mendo ${ }^{1}$ and R. Rojo-Rubio²
}

*Correspondence: glatohe@

colpos.mx

${ }^{1}$ Programa de Ganadería, Colegio de PostgraduadosCampus Montecillo, 56230 Montecillo, Edo. de México, Mexico

Full list of author information is available at the end of the article

\begin{abstract}
Objectives of this study were: (a) to compare live weight (LW) and zoometric measures (ZM) of local goats in two locations, (b) to fit the best regression equation for goat LW prediction using ZM. LW, body length (BL), trunk length $(T L)$, withers height $(W H)$, hearth girth (HG), rump width (RW), rump length (RL), head length $(H L)$, head width $(\mathrm{HW})$, and ear length (EL) were measured in 318 Local does in Amatepec and Tejupilco, State of Mexico. Statistical methods included student's " $t$ " tests for comparison of means, and correlation, principal components (PC), and multiple linear regression analyses. To evaluate the goodness of fit for $L W$ prediction models the $R^{2}$ value was used as a criterion. Differences ( $P \leq 0.05)$ were found between does of Amatepec and Tejupilco in LW, BL, TL, HG, RL, HL, HW, and EL. In Amatepec, LW was correlated with HG, $\mathrm{BL}$, and HW $(P \leq 0.01)$, whereas in Tejupilco $L W$ was correlated with $H G, B L, T L$, and HW $(P \leq 0.01)$. From the Amatepec measures $5 P C$ were extracted, and which in a multiple regression analysis explained $83.3 \%$ of the total variance, whereas from Tejupilco 4 PC were extracted, and which in a multiple regression analysis explained $82.4 \%$ of the total variance. The best regression model to predict doe $L W$ in Amatepec included TL, $H G$, RW, and HW, whereas for Tejupilco the best model included BL, HG, HW, and EL. It is concluded that: (1) Amatepec does surpass those of Tejupilco in LW and most ZM, (2) there are reliable ZM for predicting LW of local does in both locations, HG, and HW being common measures for both populations.
\end{abstract}

Keywords: Goats, Live weight, Zoometric measures, Prediction equations

\section{Background}

It has been mentioned that breed characterization is a basic step to approach the sustainable use of animal genetic resource (Lanari et al. 2003). In the State of México, México, the region with the largest goat production is located in the rural municipalities of Amatepec and Tejupilco, with about $59 \%$ of the total state goat production (RebollarRebollar et al. 2012), with a predominance of local goats (Montaldo et al. 2010). The main product of goat farming in this region is meat; consequently, the trait of major interest for genetic improvement is live weight (LW). However, for goat producers in these locations it is very difficult to measure LW because most producers lack scales in order to weigh their animals, and sale prices depend entirely on live weight. Slippers et al. (2000) consider that visual estimates are too subjective; however, Otoikhian et al.

(C) 2015 Dorantes-Coronado et al. This article is distributed under the terms of the Creative Commons Attribution 4.0 International License (http://creativecommons.org/licenses/by/4.0/), which permits unrestricted use, distribution, and reproduction in any medium, provided you give appropriate credit to the original author(s) and the source, provide a link to the Creative Commons license, and indicate if changes were made. 
(2008) indicate that it is feasible to achieve acceptable accuracy after having repeatedly estimated LW in goats by visual assessment. Nsoso et al. (2004) mentioned that it is possible to estimate LW in rural areas from the combination of zoometric measures and regression models, as a quick practice, of minimum cost and high reliability.

In Mexico, there is very little information regarding genetic and phenotypic variability of local goat populations, and even more about the efficiency of zoometric measures to estimate these parameters (Hernández Zepeda et al. 2002; Vargas et al. 2007). Objectives of the study were: (a) to compare LW and zoometric measures of local goats in two locations, and (b) to fit the best regression equation for LW prediction using zoometric measures.

\section{Methods}

\section{Animals and study area}

The present study was conducted in 17 goat production units (PU) of Amatepec and Tejupilco, located southwest of the State of Mexico, whose main characteristics are shown in Table 1. This study was conducted from February 2009 to October 2010, using 318 3-year-old local does. The management system is semi-extensive, with day grazing and night confinement. There are no regular health control practices and objective of the PU are breeding, sale of kids, and cull animals at weaning.

\section{Zoometric measures analyzed}

LW $(\mathrm{kg})$ of does was measured along with the following linear zoometric measures $(\mathrm{cm})$ : body length (BL), trunk length (TL), withers height (WH), hearth girth (HG), rump width (RW), rump length (RL), head length (HL), head width (HW), and ear length (EL). LW was measured using a hanging scale of $100 \mathrm{~kg}$ of capacity and $100 \mathrm{~g}$ of accuracy. Zoometric measures were performed with a measuring tape, a drill compass and a pediometer or a graduated measuring stick (Revidatti et al. 2007). Because pregnancy produces bias in some zoometric measures, especially in the regions of the chest and rump (Yakubu et al. 2011), only non-pregnant does were utilized in this study.

Table 1 Number of goats, climatic characteristics, altitude above sea level, and predominant forage species in Amatepec and Tejupilco, state of Mexico

\begin{tabular}{lll}
\hline Characteristics & Location & \\
\cline { 2 - 3 } & Amatepec & Tejupilco \\
\hline Number of goats & 142 & 176 \\
Climate & Temperate sub-humid & Warm sub-humid \\
Precipitation $(\mathrm{mm})^{\mathrm{a}}$ & 1840 & 1200 \\
Temperature $\left({ }^{\circ} \mathrm{C}\right)^{\mathrm{a}}$ & 22 & 27 \\
Average altitude $($ masl) & 1700 & 1200 \\
Predominant forage species & Paspalum notatum & Cynodon plectostachyus \\
& Sidarhombifolia & Brachiaria decumbens \\
& Ricinus comunnis & Andropogon gayanus \\
& Crescentia cujete & Gliricidia sepium \\
& Amaranthus hybridus & Leucaena esculenta \\
\hline
\end{tabular}

a Annual averages. Source: INEGI (2008) 


\section{Statistical methods}

To test whether differences existed in means of LW and zoometric measures between does of Amatepec and Tejupilco student's " $t$ " tests for comparison of means (Steel and Torrie 1980) were performed. Means and standard deviations were obtained and the Pearson phenotypic correlation matrix was estimated for LW and zoometric measures.

In order to reduce the number of zoometric predictor measures $(\mathrm{ZM})$ to estimate LW an analysis of principal components (APC) was carried out. This analysis allows transforming the original ZM in a new set of orthogonal variables (uncorrelated) called principal components (PC), which are a linear combination of the original variables (Johnson and Wichern 2007). In addition, APC of zoometric measures has been used as a tool in the assessment of animal body size and shape in goats (Okpeku et al. 2011). Upon APC, 9 PC were determined, and their variances, relative percentages and cumulative variances explained by the PC were obtained. The calculations were performed with the procedure PRINCOMP of SAS (SAS 2001).

For each location two multiple linear regression models were utilized to predict doe LW. The first, using as predictor variables the original ZM selected with the procedure STEPWISE of SAS (SAS 2001) based on the significance of their parameters $(P \leq 0.05)$, and the second, using as predictor variables the transformed values ("scores") of the PC, that were selected based on the percentage of the variance that the PC explained. In both models the variables were standardized with mean 0 and variance 1 , for facilitating their comparison.

The models have the following structure:

$$
\mathrm{LW}=\beta_{0}+\beta_{\mathrm{i}} \mathrm{X}_{\mathrm{i}}+\cdots+\beta_{\mathrm{n}} \mathrm{X}_{\mathrm{n}}+\epsilon \quad(\text { Model 1) }
$$

where LW is live weight, $\beta_{0}$ is the intercept of the regression equation, $\beta_{i}$ is the ith partial regression coefficient of the ith zoometric measure retained in the model $\left(X_{i}\right)$, $\beta_{n}$ is the nth partial regression coefficient of the nth zoometric measure retained in the model $\left(\mathrm{X}_{\mathrm{n}}\right), \varepsilon$ is the random error.

$$
\mathrm{LW}=\gamma_{0}+\gamma_{\mathrm{i}} \mathrm{PC}_{\mathrm{i}}+\cdots+\gamma_{\mathrm{n}} \mathrm{PC}_{\mathrm{n}}+\epsilon \quad(\text { Model 2) }
$$

where LW is live weight, $\gamma_{0}$ is the intercept of the regression equation, $\gamma_{\mathrm{i}}$ is the ith partial regression coefficient of scores of the ith principal component $\left(\mathrm{PC}_{\mathrm{i}}\right), \gamma_{\mathrm{n}}$ is the nth partial regression coefficient of scores of the nth principal component $\left(\mathrm{PC}_{n}\right), \varepsilon$ is the random error.

The criterion to evaluate goodness of fit of models used was based on the $R^{2}$ value (Kleinbaum and Kupper 1978).

\section{Results}

Descriptive statistics

Table 2 shows descriptive statistics for LW and zoometric measures of goats from the two locations studied. Amatepec does were heavier, had a longer body, trunk, rump, head, and ear, and also a higher hearth girth than Tejupilco does. 
Table 2 Least-squares means of live weight and zoometric measures of local goats in Amatepec and Tejupilco, state of Mexico

\begin{tabular}{|c|c|c|c|c|}
\hline \multirow[t]{2}{*}{ Variable } & \multicolumn{2}{|c|}{ Amatepec $(n=142)$} & \multicolumn{2}{|c|}{ Tejupilco $(n=176)$} \\
\hline & Mean & SD & Mean & SD \\
\hline LW (kg) & $34.5 \mathrm{a}$ & 7.2 & $32.0 \mathrm{~b}$ & 8.9 \\
\hline $\mathrm{BL}(\mathrm{cm})$ & $104.5 \mathrm{a}$ & 8.4 & $98.9 b$ & 9.6 \\
\hline $\mathrm{TL}(\mathrm{cm})$ & $67.8 \mathrm{a}$ & 5.3 & $66.5 b$ & 6.6 \\
\hline $\mathrm{WH}(\mathrm{cm})$ & $66.2 \mathrm{a}$ & 4.9 & $66.4 \mathrm{a}$ & 5.4 \\
\hline $\mathrm{HG}(\mathrm{cm})$ & $77.3 \mathrm{a}$ & 6.6 & $74.7 b$ & 6.7 \\
\hline RW (cm) & $13.7 \mathrm{a}$ & 2.0 & $14.0 \mathrm{a}$ & 1.8 \\
\hline $\mathrm{RL}(\mathrm{cm})$ & $19.7 \mathrm{a}$ & 2.3 & $18.4 b$ & 3.1 \\
\hline $\mathrm{HL}(\mathrm{cm})$ & $20.8 \mathrm{a}$ & 2.1 & $20.2 b$ & 2.4 \\
\hline $\mathrm{HW}(\mathrm{cm})$ & $11.6 b$ & 1.0 & $12.7 \mathrm{a}$ & 1.3 \\
\hline $\mathrm{EL}(\mathrm{cm})$ & $18.3 \mathrm{a}$ & 2.6 & $17.3 \mathrm{~b}$ & 2.9 \\
\hline
\end{tabular}

$\mathrm{a}, \mathrm{b}$ : different letters between rows differ $(P \leq 0.05)$

$L W$ live weight, $B L$ body length, $T L$ trunk length, $W H$ withers height, $H G$ hearth girth, $R W$ rump width, $R L$ rump length, $H L$ head length, $H W$ head width, EL ear length, SD standard deviation

\section{Phenotypic correlations}

The matrix of phenotypic correlations between live weight and zoometric measures is shown in Table 3. The highest phenotypic correlations $(P \leq 0.01)$ were found between LW and HG (0.83), HG and TL (0.75), BL and TL (0.74), HG and WH (0.73), LW and BL (0.72), and LW and HG (0.71). Except for EL, LW was highly correlated $(P \leq 0.01)$ with all zoometric measures.

\section{Principal components and explained variances}

From LW and nine zoometric measures of Amatepec does 5 PC were extracted which accounted for $83.3 \%$ of the total variance (Table 4). From the analysis of Tejupilco does only 4 PC's were extracted, which accounted for $82.4 \%$ of the total variance.

Table 3 Matrix of phenotypic correlations between live weight and zoometric measures of local goats in Amatepec (above main diagonal) and Tejupilco (below main diagonal), state of Mexico

\begin{tabular}{|c|c|c|c|c|c|c|c|c|c|c|}
\hline & LW & $B L$ & $\mathrm{TL}$ & WH & HG & RW & RL & $\mathrm{HL}$ & HW & EL \\
\hline LW & & $0.63^{\mathrm{a}}$ & $0.48^{\mathrm{a}}$ & $0.49^{\mathrm{a}}$ & $0.83^{\mathrm{a}}$ & $0.52^{\mathrm{a}}$ & $0.33^{\mathrm{a}}$ & $0.40^{\mathrm{a}}$ & $0.53^{\mathrm{a}}$ & $0.00^{\text {ns }}$ \\
\hline $\mathrm{BL}$ & $0.72^{\mathrm{a}}$ & & $0.53^{\mathrm{a}}$ & $0.53^{\mathrm{a}}$ & $0.62^{\mathrm{a}}$ & $0.50^{\mathrm{a}}$ & $0.50^{\mathrm{a}}$ & $0.49^{\mathrm{a}}$ & $0.40^{\mathrm{a}}$ & $0.09^{\text {ns }}$ \\
\hline $\mathrm{TL}$ & $0.67^{\mathrm{a}}$ & $0.74^{\mathrm{a}}$ & & $0.53^{\mathrm{a}}$ & $0.39^{\mathrm{a}}$ & $0.38^{\mathrm{a}}$ & $0.52^{\mathrm{a}}$ & $0.28^{\mathrm{a}}$ & $0.33^{\mathrm{a}}$ & $0.32^{\mathrm{a}}$ \\
\hline WH & $0.67^{\mathrm{a}}$ & $0.67^{\mathrm{a}}$ & $0.66^{\mathrm{a}}$ & & $0.46^{\mathrm{a}}$ & $0.35^{\mathrm{a}}$ & $0.35^{\mathrm{a}}$ & $0.22^{\mathrm{a}}$ & $0.42^{\mathrm{a}}$ & $0.19^{b}$ \\
\hline $\mathrm{HG}$ & $0.71^{\mathrm{a}}$ & $0.68^{\mathrm{a}}$ & $0.75^{\mathrm{a}}$ & $0.73^{\mathrm{a}}$ & & $0.47^{\mathrm{a}}$ & $0.29^{\mathrm{a}}$ & $0.41^{\mathrm{a}}$ & $0.47^{\mathrm{a}}$ & $-0.06^{\mathrm{ns}}$ \\
\hline RW & $0.53^{\mathrm{a}}$ & $0.61^{\mathrm{a}}$ & $0.63^{\mathrm{a}}$ & $0.57^{\mathrm{a}}$ & $0.65^{\mathrm{a}}$ & & $0.41^{\mathrm{a}}$ & $0.34^{\mathrm{a}}$ & $0.38^{\mathrm{a}}$ & $0.12^{\mathrm{ns}}$ \\
\hline $\mathrm{RL}$ & $0.55^{\mathrm{a}}$ & $0.59^{\mathrm{a}}$ & $0.58^{\mathrm{a}}$ & $0.58^{\mathrm{a}}$ & $0.48^{\mathrm{a}}$ & $0.46^{\mathrm{a}}$ & & $0.38^{\mathrm{a}}$ & $0.07^{\mathrm{ns}}$ & $0.34^{\mathrm{a}}$ \\
\hline $\mathrm{HL}$ & $0.59^{\mathrm{a}}$ & $0.66^{\mathrm{a}}$ & $0.61^{\mathrm{a}}$ & $0.61^{\mathrm{a}}$ & $0.61^{\mathrm{a}}$ & $0.62^{\mathrm{a}}$ & $0.54^{\mathrm{a}}$ & & $0.38^{\mathrm{a}}$ & $0.21^{b}$ \\
\hline $\mathrm{HW}$ & $0.53^{\mathrm{a}}$ & $0.55^{\mathrm{a}}$ & $0.54^{\mathrm{a}}$ & $0.55^{\mathrm{a}}$ & $0.52^{\mathrm{a}}$ & $0.56^{\mathrm{a}}$ & $0.41^{\mathrm{a}}$ & $0.41^{\mathrm{a}}$ & & $0.02^{\mathrm{ns}}$ \\
\hline EL & $0.42^{\mathrm{a}}$ & $0.35^{\mathrm{a}}$ & $0.37^{a}$ & $0.48^{\mathrm{a}}$ & $0.37^{\mathrm{a}}$ & $0.26^{\mathrm{a}}$ & $0.45^{\mathrm{a}}$ & $0.45^{\mathrm{a}}$ & $0.20^{b}$ & \\
\hline
\end{tabular}

${ }^{a} P \leq 0.05,{ }^{b} P \leq 0.01$, ns non-significant 
Table 4 Principal components (PC), variance, partially explained variance, and cumulatively explained variance from the principal components analysis carried out for zoometric measures of local goats in Amatepec and Tejupilco, state of México

\begin{tabular}{|c|c|c|c|c|c|c|c|}
\hline \multicolumn{4}{|c|}{ Amatepec } & \multicolumn{4}{|c|}{ Tejupilco } \\
\hline PC & Variance & $\begin{array}{l}\text { Partially } \\
\text { explained } \\
\text { variance (\%) }\end{array}$ & $\begin{array}{l}\text { Cumulatively } \\
\text { explained } \\
\text { variance (\%) }\end{array}$ & PC & Variance & $\begin{array}{l}\text { Partially } \\
\text { explained } \\
\text { variance (\%) }\end{array}$ & $\begin{array}{l}\text { Cumulatively } \\
\text { explained } \\
\text { variance (\%) }\end{array}$ \\
\hline$P C_{1}$ & 3.9 & 43.8 & 43.8 & $\mathrm{PC}_{1}$ & 5.4 & 60.2 & 60.2 \\
\hline$P C_{2}$ & 1.3 & 14.6 & 58.4 & $\mathrm{PC}_{2}$ & 0.9 & 10.3 & 70.5 \\
\hline$P C_{3}$ & 0.8 & 9.4 & 67.8 & $\mathrm{PC}_{3}$ & 0.5 & 6.2 & 76.7 \\
\hline $\mathrm{PC}_{4}$ & 0.8 & 8.7 & 76.5 & $\mathrm{PC}_{4}$ & 0.5 & 5.7 & 82.4 \\
\hline$P C_{5}$ & 0.6 & 6.8 & 83.3 & $\mathrm{PC}_{5}$ & 0.4 & 5.1 & 87.5 \\
\hline$P C_{6}$ & 0.4 & 5.0 & 88.3 & $\mathrm{PC}_{6}$ & 0.3 & 3.9 & 91.4 \\
\hline$P C_{7}$ & 0.4 & 4.5 & 92.8 & $\mathrm{PC}_{7}$ & 0.3 & 3.6 & 95.0 \\
\hline$P C_{8}$ & 0.3 & 3.7 & 96.5 & $P C_{8}$ & 0.2 & 2.7 & 97.7 \\
\hline $\mathrm{PC}_{9}$ & 0.3 & 3.5 & 100.0 & $P C_{9}$ & 0.2 & 2.3 & 100.0 \\
\hline
\end{tabular}

\section{Selected live weight prediction equations}

Under the situation of Model 1 from the multiple linear regression analysis, the best model for Amatepec does included TL, HG, RW, and HW, with a value of $\mathrm{R}^{2}=0.82$ (Table 5), while for Tejupilco does the best model included BL, HG, HW, and EL with a value of $\mathrm{R}^{2}=0.78$, HG and HW being common measures for both populations.

\section{Discussion}

\section{Live weight and zoometric measures}

The longer ears of Amatepec does, in addition to their superiority in LW and other zoometric measures, suggest the possibility that they have a higher influence of the Nubian breed than Tejupilco does, a breed that has been classified as a dual-purpose goat breed (Merlos-Brito et al. 2008). Local does of the State of Mexico have slightly lower or larger measures in various zoometrical traits than local does in different regions of México (Hernández Zepeda et al. 2002; Vargas et al. 2007), Venezuela (Pariacote et al. 2004), Argentina (Revidatti et al. 2007), and Cuba (Chacón et al. 2011). These differences can be mainly attributed to climate-related factors which generally produce changes in the quantity and quality of vegetation in different agro-ecological zones, thus leading to different ecotypes (Dossa et al. 2007). In addition, they can be also an effect of natural or artificial selection.

\section{Phenotypic correlations}

High correlations were found between HG and BL with LW $(P \leq 0.01)$ in both populations (Table 3), which coincides with results obtained by Pariacote et al. (2004). This result suggests that producers who lack scales for weighing animals can estimate LW of their goats using either of those two zoometric measures; that is, they can use a tape rule instead of a weighing scale, a practice that is much easier to perform under field conditions. 
Table 5 Multiple linear regression (stepwise) of live weight on original (model 1) and orthogonal (model 2) variables of local goats in Amatepec and Tejupilco, state of Mexico

\begin{tabular}{|c|c|c|c|c|c|c|c|c|c|}
\hline \multicolumn{5}{|c|}{ (1) Original variables as predictors } & \multicolumn{5}{|c|}{ (2) Orthogonal variables as predictors } \\
\hline Variables & $\beta_{1}$ & SE & $a$ & $\mathrm{R}^{2}$ & PC & $\beta_{1}^{*}$ & SE & $a$ & $\mathrm{R}^{2}$ \\
\hline \multicolumn{10}{|l|}{ Amatepec } \\
\hline$B L$ & 0.08 & 0.05 & 0.14 & 0.82 & $P C_{1}$ & 0.37 & 0.02 & 0.00 & 0.74 \\
\hline$T L$ & 0.18 & 0.07 & 0.01 & & $P C_{2}$ & -0.28 & 0.04 & 0.00 & \\
\hline WH & 0.06 & 0.08 & 0.46 & & $P C_{3}$ & -0.06 & 0.05 & 0.18 & \\
\hline$H G$ & 0.73 & 0.06 & 0.00 & & $\mathrm{PC}_{4}$ & -0.08 & 0.05 & 0.10 & \\
\hline RW & 0.39 & 0.19 & 0.04 & & $\mathrm{PC}_{5}$ & 0.01 & 0.06 & 0.86 & \\
\hline $\mathrm{RL}$ & 0.08 & 0.17 & 0.64 & & $\mathrm{PC}_{6}$ & -0.13 & 0.07 & 0.06 & \\
\hline $\mathrm{HL}$ & -0.11 & 0.14 & 0.43 & & $P C_{7}$ & 0.40 & 0.07 & 0.00 & \\
\hline HW & 0.94 & 0.36 & 0.01 & & $P C_{8}$ & 0.22 & 0.08 & 0.00 & \\
\hline EL & -0.06 & 0.13 & 0.67 & & $\mathrm{PC}_{9}$ & -0.02 & 0.08 & 0.78 & \\
\hline$\beta_{0}$ & -49.87 & & & & $\gamma_{0}$ & 0.00 & & & \\
\hline \multicolumn{10}{|l|}{ Tejupilco } \\
\hline$B L$ & 0.34 & 0.06 & 0.00 & 0.76 & $P C_{1}$ & 0.34 & 0.02 & 0.00 & 0.76 \\
\hline TL & 0.09 & 0.11 & 0.42 & & $P C_{2}$ & 0.01 & 0.05 & 0.90 & \\
\hline WH & 0.17 & 0.13 & 0.18 & & $P C_{3}$ & 0.02 & 0.06 & 0.73 & \\
\hline$H G$ & 0.46 & 0.09 & 0.00 & & $P C_{4}$ & -0.04 & 0.06 & 0.51 & \\
\hline RW & -0.22 & 0.32 & 0.50 & & $\mathrm{PC}_{5}$ & -0.19 & 0.07 & 0.00 & \\
\hline$R L$ & 0.25 & 0.17 & 0.14 & & $P C_{6}$ & -0.13 & 0.08 & 0.09 & \\
\hline $\mathrm{HL}$ & 0.17 & 0.25 & 0.49 & & $P C_{7}$ & -0.04 & 0.06 & 0.62 & \\
\hline HW & 0.79 & 0.38 & 0.04 & & $P C_{8}$ & 0.05 & 0.09 & 0.58 & \\
\hline EL & 0.43 & 0.15 & 0.01 & & $\mathrm{PC}_{9}$ & 0.23 & 0.10 & 0.03 & \\
\hline$\beta_{0}^{*}$ & -54.15 & & & & $\gamma_{0}^{*}$ & 0.00 & & & \\
\hline
\end{tabular}

$B L$ body length, $T L$ trunk length, $W H$ withers height, $H G$ hearth girth, $R W$ rump width, $R L$ rump length, $H L$ head length, $H W$ head width, EL ear length, $P C$ principal component, SE standard error, a probability value, $R^{2}$ coefficient of determination

\section{Principal components and explained variances}

Okpeku et al. (2011) compared West African Dwarf (WAD) and Red Sokoto (RS) goats in LW and four zoometric measures by performing an APC, and extracted $2 \mathrm{PC}$ in each breed. Moreover, the 2 PC extracted in WAD goats explained $94.15 \%$ of the total variance, while the 2 PC extracted in RS goats explained $91.25 \%$ of the total variance. Pariacote et al. (2004) performed an APC with 10 zoometric measures in local goats and extracted 10 PC, which explained $81 \%$ of the total variation. López-Carlos et al. (2010) indicated that the first PC represent general body size, while the second PC represent body shape or conformation.

\section{Selected live weight prediction equations}

Regarding HG, Leng et al. (2010) recommended the use of this trait as a reliable measure to predict LW in goats under field conditions, due to the fact that muscle, some fat, and bone structure contribute to its formation. Bello and Adama (2012) also found that HG was the best zoometric measure to predict LW in goats. Similar to the results of Tejupilco, Ribeiro et al. (2004) found that the best model to predict LW in local goats and their crosses included BL and HG. 
Under the situation of Model 2 of the multiple regression analysis, the best model for Amatepec goats included $\mathrm{PC}_{1}, \mathrm{PC}_{2}, \mathrm{PC}_{7}$, and $\mathrm{PC}_{8}$, with a value of $\mathrm{R}^{2}=0.76$ (Table 5), while for Tejupilco goats the best model included $\mathrm{PC}_{1}, \mathrm{PC}_{5}$ and $\mathrm{PC}_{9}$, with a similar $\mathrm{R}^{2}$ value.

From a global analysis, considering situations of Models 1 and 2 from the multiple linear regression analysis, we conclude that the model to be used for Amatepec goats is that one that includes original variables as predictors of LW, due to their higher value of $\mathrm{R}^{2}$ (0.82), compared to the model that includes orthogonal variables as predictors of $L W$, which had a lower value of $R^{2}(0.74)$. For Tejupilco goats the value of $R^{2}$ was similar (0.76) under the situations of Models 1 and 2 from the multiple regression analysis, thus to predict LW of goats in this population either model can be used.

\section{Conclusion and implications}

There are significant $(P \leq 0.01)$ differences between local does of Amatepec and Tejupilco in live weight, body length, trunk length, hearth girth, rump length and width, head length, and ear length. Trunk length, hearth girth, rump width and head width are zoometric reliable measures for predicting live weight of Amatepec local does, while for Tejupilco does body length, hearth girth, head width, and ear length are the most informative measures. Since hearth girth and head width are measures common to both populations, producers who lack scales for weighing animals in those locations are therefore recommended to utilize those measures to estimate live weight of goats with a good reliability. In addition, they will find that the use of a tape rule or graduated measuring stick signifies the saving of a considerable time and labor, especially when they are ready to sell goats based on live weight.

Authors' contributions

EJDC and RRR collected field data, EJDC, GTH and OHM performed statistical analyses, EJDC and GTH prepared the manuscript. All authors read and approved the final manuscript.

Author details

${ }_{1}^{1}$ Programa de Ganadería, Colegio de Postgraduados-Campus Montecillo, 56230 Montecillo, Edo. de México, Mexico.

2 Universidad Autónoma del Estado de México-Unidad Temascaltepec, Temascaltepec, Edo. De México, Mexico.

Competing interests

The authors declare that they have no competing interests.

Ethical guidelines

The experimental protocol utilized with the animals in this study completely adhered to ethical issues, since international recognized guidelines were followed.

Received: 26 January 2015 Accepted: 9 October 2015

Published online: 12 November 2015

\footnotetext{
References

Bello AA, Adama TZ (2012) Studies on body weight and linear body measurements of castrates and non-castrate Savannah Brown goats. Asian J Anim Sci 6:140-146

Chacón E, Macedo F, Velázquez F, Paiva SR, Pineda E, McManus C (2011) Morphological measurements and body indices for Cuban Creole goats and their crossbreds. Revista Brasileira de Zootecnia 40:1671-1679

Dossa LH, Wollny C, Gauly M (2007) Spatial variation in goat populations from Benin as revealed by multivariate analysis of morphological traits. Small Rumin Res 73:150-159

Hernández Zepeda JS, Franco Guerra FJ, Herrera García M, Rodero Serrano E, Sierra Vázquez AC, Bañuelos Cruz A, Delgado Bermejo JV (2002) Estudio de los recursos genéticos de México: características morfológicas y morfoestructurales de los caprinos nativos de Puebla. Archivos de Zootecnia 51:53-64

INEGI (2008) Anuario Estadístico del Estado de México. Instituto Nacional de Estadística, Geografía, e Informática, México Johnson RA, Wichern DW (2007) Applied multivariate statistical analysis. Prentice Hall, Upper Saddle River, p 773
} 
Kleinbaum DG, Kupper LL (1978) Applied regression analysis and other multivariable methods. Duxbury Press, North Scituate, p 556

Lanari MR, Taddeo H, Domingo E, Pérez Centeno M, Gallo L (2003) Phenotypic differentiation of exterior traits in local Criollo goat population in Patagonia (Argentina). Archiv Fur Tierzucht Dummerstorf 46:347-356

Leng J, Zhu R, Zhao G, Yang Q, Mao H (2010) Quantitative and qualitative body traits of longling yellow goats in China. Agric Sci China 9:408-415

López-Carlos MA, Ramírez RG, Aguilera-Soto JL, Aréchiga CF, Rodríguez H (2010) Size and shape analyses in hair sheep ram lambs and its relationship with growth performance. Livest Sci 131:203-211

Merlos-Brito MI, Martínez-Rojero RD, Torres-Hernández G, Mastache-Lagunas AA, Gallegos-Sánchez J (2008) Evaluation of productive traits in Boer x local Nubian x local and local kids in the dry tropic of Guerrero, México. Veterinaria México 39:323-333

Montaldo HH, Torres-Hernández G, Valencia-Posadas M (2010) Goat breeding research in México. Small Rumin Res 89:155-163

Nsoso SJ, Podisi B, Otsogile E, Mokhutshwane BS, Ahmadu B (2004) Phenotypic characterization of indigenous Tswana goats and sheep breeds in Botswana: continuous traits. Trop Anim Health Prod 36:789-800

Okpeku M, Yakubu A, Peters SO, Ozoje MO, Ikeobi CON, Adebambo OA, Imumorin IG (2011) Application of multivariate principal component analysis to morphological characterization of indigenous goats in Southern Nigeria. Acta Agriculturae Slovenica 98:101-109

Otoikhian CSO, Otoikhian AM, Akporhuarho OP, Oyefia VE, Isidahomen CE (2008) Body measurement parameters as a function of assessing body weight in goats under on-farm research environment. Afr J Gen Agric 4:135-140

Pariacote FA, Ruiz L, Ascencao DCD', Borges C, Pimentel X (2004) Características morfológicas del caprino Criollo venezolano. Archivos Latinoamericanos de Producción Animal 12:16-21

Rebollar-Rebollar S, Hernández-Martínez J, Rojo-Rubio R, Guzmán-Soria E (2012) Gastos e ingresos en la actividad caprina extensiva en México. Agronomía Mesoamericana 23:159-165

Revidatti MA, Prieto PN, de La Rosa S, Ribeiro MN, Capellari A (2007) Cabras Criollas de la región norte de Argentina. Estudio de variables e índices zoométricos, Archivos de Zootecnia 56:479-482

Ribeiro NL, Medeiros AN, Ribeiro MN, y Pimenta Filho EC (2004) Estimación del peso vivo de caprinos autóctonos brasileños mediante medidas morfométricas. Archivos de Zootecnia 53:341-344

SAS (2001) SAS/STAT User's Guide, Release 8.2. SAS Institute Inc, Cary

Slippers SC, Letty BA, de Villiers JF (2000) Prediction of the body weight of Nguni goats. S Afr J Anim Sci 30(Supplement 1):127-128

Steel RGD, Torrie JH (1980) Principles and procedures of statistics, 1st edn. McGraw-Hill, New York

Vargas S, Larbi A, Sánchez M (2007) Analysis of size and conformation of native Creole goat breeds and crossbreds used in smallholder agrosilvopastoral systems in Puebla, Mexico. Trop Anim Health Prod 39:279-286

Yakubu A, Ladokun AO, Adua MM (2011) Bioprediction of body weight from zoometrical traits of non-descript goats using linear and non-linear models in North Central Nigeria, Livestock Research for Rural Development. http://www. Irrd.org/lrrd23/6/yaku23130.htm. Accessed 18 Mar 2013

\section{Submit your manuscript to a SpringerOpen ${ }^{\circ}$ journal and benefit from:}

- Convenient online submission

- Rigorous peer review

- Immediate publication on acceptance

- Open access: articles freely available online

- High visibility within the field

- Retaining the copyright to your article

Submit your next manuscript at $\mathbf{s p r i n g e r o p e n . c o m ~}$ 